\title{
Effects of mineral reactivity and seasonality on enhanced rock weathering of kimberlite mine residues
}

\author{
CARLOS PAULO ${ }^{1}$, IAN M. POWER ${ }^{1}$, AMANDA R. \\ STUBBS $^{1}$, SENZENI NDLOVU ${ }^{2}$, KHANGEZIWE SENZANI ${ }^{2}$, \\ ANDREW VIETTI ${ }^{3}$ AND HENRY MAY ${ }^{3}$ \\ ${ }^{1}$ Trent University \\ ${ }^{2}$ De Beers Group Technology, Johannesburg \\ ${ }^{3}$ Vietti Slurrytec, Johannesburg \\ Presenting Author: cfernandesesilvapaul@trentu.ca
}

Kimberlite residues at diamond mines have the ability to remove carbon dioxide $\left(\mathrm{CO}_{2}\right)$ from the atmosphere through weathering processes that can be accelerated by implementing new management practices that enhance mineral dissolution and $\mathrm{CO}_{2}$ supply. ${ }^{1,2}$ Field experiments $\left(\mathrm{m}^{3}\right.$-scale) were conducted (February 2020 onward) using fine $(<1 \mathrm{~mm})$ and coarse $(1-8$ $\mathrm{mm}$ ) kimberlites residues from Venetia Diamond Mine (South Africa) as part of De Beers' Project CarbonVault ${ }^{\mathrm{TM}}$. These experiments aimed to monitor $\mathrm{CO}_{2}$-aqueous-rock interactions and determine $\mathrm{CO}_{2}$ removal rates under current mine conditions (control) and practices that further enhance rock weathering (ERW) including intensifying wet-dry cycles, tilling, and the use of organics. Volumetric water content, conductivity, temperature, and $\mathrm{CO}_{2}$ concentrations in the residues were measured remotely using a network of sensors. Porewaters and solids were routinely collected to develop geochemical and pedogenetic models. $\mathrm{CO}_{2}$ removal rates in the field were greatly influenced by kimberlite reactivity, climate seasonality, and ERW practices. Periods of higher rainfall and temperature were linked to greater $\mathrm{CO}_{2}$ ingress, whereas in the dry and cooler season, a hardpan limited $\mathrm{CO}_{2}$ ingress. In contrast, surface tilling and water content optimization resulted in greater $\mathrm{CO}_{2}$ ingress in the ERW experiments. In the coarse residues amended with organics, $\mathrm{CO}_{2}$ increased from approximately $0.04 \%$ to $2 \%$ due to microbial respiration. As a result, alkalinity increased from 4 to $20 \mathrm{mmol}$ indicating greater solubility trapping of $\mathrm{CO}_{2}$. Greater cation release was also observed in ERW experiments, predominantly when ERW practices were intensified. ERW also showed a positive impact in potassium leaching from kimberlite that can be beneficial for establishing vegetation on mine residues as part of mine restoration. With ERW, the average $\mathrm{CO}_{2}$ mineralization rate increased from an initial 40 to $66 \mathrm{~g} \mathrm{CO}_{2} / \mathrm{m}^{2} / \mathrm{yr}$ and from 8 to $29 \mathrm{~g} \mathrm{CO}_{2} / \mathrm{m}^{2} / \mathrm{yr}$ in the fine and coarse residues, respectively. Our field experiments provide insights into kimberlite residue weathering, estimate ERW rates, and identify management practices that promote greater $\mathrm{CO}_{2}$ removal. [1] Mervine et al. (2018), Mineral. Petrol. 112, 755-765 [2] Wilson et al. (2011), Environ. Sci. Technol. 45, 7727-7736. 